\title{
The formation, structure, and electronic properties of Lansoprazol drug and cucurbit [7]urils complex (Theoretical Study)
}

\section{Hamdia H.Jawad Al-Shammary*} Waleed Madhloom Khalaf**

*Department of Chemistry, College of Science for Women, University of Baghdad. **Police College, Ministry of Interior, Baghdad, Iraq. Emil: Hamdiahateem@yahoo.com

Received 20/10/2015

Accepted 20/12/2015

\section{(i) $(9)$}

EY NC ND This work is licensed under a Creative Commons Attribution-NonCommercialNoDerivatives 4.0 International Licens

\begin{abstract}
:
The current study deals with host-guest complex formation between cucurbit [7] urils as host and lansoprazole as guest using PM3 (semi empirical molecules orbital calculations) also DFT calculations. In this complex, the formation of hydrogen bonding may be occurred through portal oxygen atoms $\left(\mathrm{O}_{2}\right)$ of cucurbit [7] urils and amine groups $\left(\mathrm{NH}_{2}\right)$ of the drug. The energies of HOMO and LUMO orbital's have been computed for the host guest complex and its components. The result of the stabilization energy explained a complex formation.
\end{abstract}

Key words: host- guest complex, Semiemprical PM3, DFT calculation, lansoprazol, electronic properties.

\section{Introduction:}

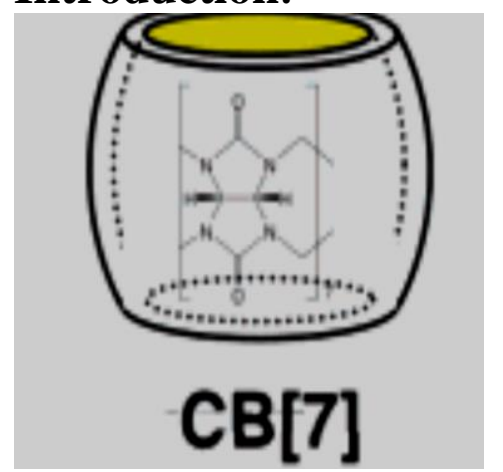

Fig. (1): Structure of CB [7]

The explication of the molecular structure of a cucurbit [6] uril by Mock, 1981, cucurbit [n]urils $(n=5-10)$ has been gradually established like versatile host molecules of an inclusion of lesser guest. Several homologues cucurbit turil were cucurbit [7] uril that was shown in (figure1) has attracted more attraction owing to its best solubility in water than others a solution. Many reported were shown in last years, CB[7] with inclusion complexes molecular for $\mathrm{CB}[7]$. Containing cationic neutral species solution. As well as, compared with the $2^{\text {ed }}$ generation of the host molecules (cyclodextrins), which was widely used in pharmacological fields , many manufacturing products, analytical methods and technologies related investigation of cucurbit[n] uril were still in preliminary steps. So, the investigation of important studies for understanding the properties of 
cucurbit[n] urils is still an essential topic at the present [1]. Cucurbit[n]uril $\mathrm{CB}[\mathrm{n}]$ $(n=5-8)$ or more are "the cyclic methylene bridged glycouril oligomers that represent fascinating class of molecules which were composed of the hydrophobic cavity surrounded by hydrophilic portals lined up the polar Uredo the carbonyl groups"[2]Cucurbit [7] uril crowd molecules that have the latent to encapsulate biologically relevant guests and it is act as drug transporters, stabilizer's ,solubilizes , this drug bioavailability enhancers[3]. Cucurbit [7] uril that has greatly symmetrical structures with the hydrophobic cavity and accessible in both sides through two identical carbonyl rimmed portals that shown in Figure (1). The function of this molecular that containers forming strong non covalent 1:1 also 2:1 host-guest inclusion complexes with neutral and positive(+ve) charged organic molecules[4]. CB [7] the complexion of deal with the several drugs administrated by the gastrointestinal tract, such as: omeprazole and lansoprazole proton pump inhibitors (PPIs); their encapsulation in cucurbituril may be changes in the (pKa) values of these drugs, thereby improving their stabilization and activation. The H-receptor of histamine antagonist ranitidine demonstrations the $\mathrm{pKa}$ that may be shifting through encapsulation and is thereby stabilized [5].In the current study, suggested that the molecules modeling system of hostguest complex between the CB[7] and lansoprazol to study the stability and structure of that complex molecule. .

\section{Methodology:}

1- The structures of all the module of host-guest compound were optimized by default methods.

2- All these computation were performed with HyperChem7.1 package "(Hypercube Inc. Gainesville, FL.)" the quantum mechanical program for theoretical computations.

3- The energy was minimized by PM3 [6] semi empirical method as well as DFT [7] was calculated.

4- To get the optimized of the structure and minimum energy of the host- guest complex formation with using PM3, the optimum host molecule position to guest molecule position, it should be obtained.

5- The calculations in an investigation were performed in a gas phase.

\section{Results and Discussion:}

The optimized geometry of cucurbit [7] was consistent with the earlier experimental and modeling results [8-9]. The optimized structures of the cucurbit [7] the urils were found to possess a Dnh symmetry and are revealed in supporting information as Figur 2. The structural parameter for that is provided in Table 1. Cavity diameter is about $11.7478 \mathrm{~A}^{\circ}$ and the height is $5.7618 \mathrm{~A}^{\circ}$ with ring size as shown in Table 1. The calculated intermolecular distance between the oxygen portals for CB [7] is $7.71 \mathrm{am}^{\circ}$ respectively, which are in agreement with the previously reported values [10]. The calculated HOMO-LUMO band gap values are in close to the previously reported values [11]. 
The $2^{\text {nd }}$ National Conference of Chemistry

Table (1): DFT (B3LYP) calculation Selected geometrical parameters for optimized geometrics (in $\mathrm{A}^{\circ}$ ) and the calculated HOMO-LUMO band gap in (eV) for CB [7]

\begin{tabular}{|l|l|l|l|l|l|l|}
\hline $\begin{array}{l}\text { Diameter } \\
\text { ofoxygen } \\
\text { portal }\end{array}$ & $\begin{array}{l}\text { Cavity } \\
\text { diameter A }\end{array}$ & $\begin{array}{l}\text { Outer } \\
\text { diameter A }\end{array}$ & height $\mathrm{A}^{\circ}$ & $\mathrm{E}_{\text {Hомо }}(\mathrm{eV})$ & $\mathrm{E}_{\text {LUmо }}(\mathrm{eV})$ & $\begin{array}{l}\text { HOMO- } \\
\text { LUMO } \\
\text { energy } \\
\text { gap(eV) }\end{array}$ \\
\hline 7.7069 & 11.7478 & 7.8618 & 5.7618 & -9.5788 & 0.4637 & 9.1151 \\
\hline
\end{tabular}

To determine the geometries of the possible cucurbit [7] uril-lansoprazol complexes, lansoprazol was placed inside the cavity of $\mathrm{CB}[7]$ and allowed to relax. Since the previous X-ray crystal structure of CB [7]-oxaliplatin [12] complex has a geometry in which cyclohexane was present inside the cavity of CB [7], we have restricted our studies to this position. The optimized geometries for the inclusion complexes are shown in Figure2.

The intermolecular distance between the oxygen portals are enlarged in one direction and are reduced in the perpendicular distance. This shows that cucurbit urils are flexible hosts and could accommodate large guests. The amine nitrogen atoms of the lasoprazol guest lie on the plane of the portal oxygen atoms, with the possible existence of a hydrogen bonding.

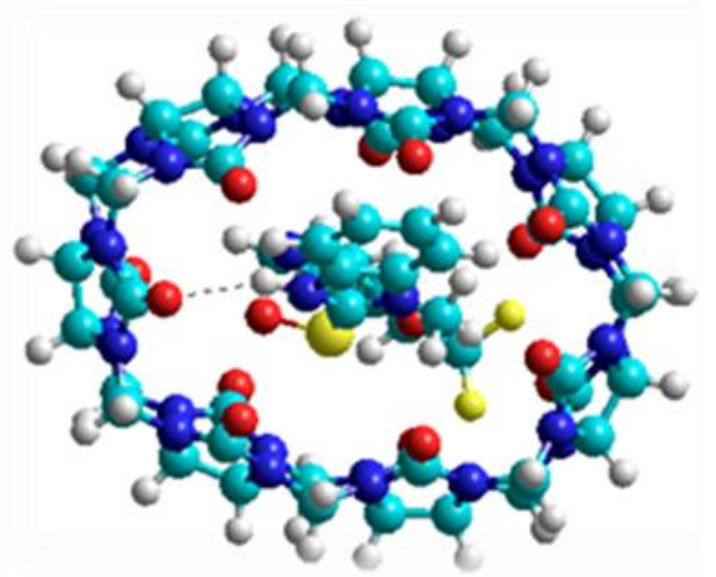

Fig. (2): Optimized structures of a CB[7]- lansoprazol complex and show the hydrogen bonding. Color codes: carbon, gray; nitrogen, blue; oxygen, red, sulfur and fluorine, yellow. 
Energetic

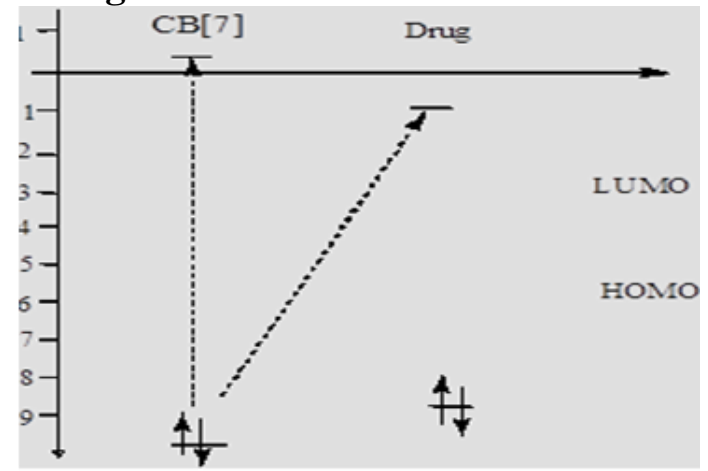

Fig. (3): $\mathrm{E}_{\text {HOMо }}(\mathrm{eV})$ and $\mathrm{E}_{\mathrm{LUmo}}(\mathrm{eV})$ levels

To understand the stability and formation of the inclusion complex, should be calculated the formation energy and the thermodynamic parameters of CB [7] with lansoprazol like the host at the PM3 theory the results are shown in Table 2 and Table 3. Throughout the formation of inclusion complex from cucurbit [7]uril and lansoprazol. In the next Table in this study the negative values of heat of formation of the inclusion complex show the stability of the complex, the electronic energy (E), certify the fact because the inverse values and the values of HOMO (highest occupied molecular orbital) and LUMO (lowest unoccupied molecular orbital) and band gap values is a quantity of the excitability of the complex.

In Fig. (4b) show interaction between medication and CB [7] It is clear in this figure $\mathrm{E}_{\mathrm{LUMO}}$ for drug lowest than $E_{L U M O}$ for $C B$ [7] so interaction between them was happened. The occupied molecular orbital (HOMO) of CB [7]-lansoprazol complex was high and the unoccupied molecular orbital (LUMO) shown in Figure 4 was low. The HOMO orbital localized on the benzene ring and imidazole ring in the medical material (drug) and the LUMO orbital are localized on the cucurbit uril unit in the CB [7]-lansoprazol complex orbital. The strength of the interaction determined here reflects the ability of cucurbit [7]urils to act as a host for suitably lansoprazol guests, even in aqueous solution.

Table (2): Thermodynamic parameters for CB [7].

\begin{tabular}{|c|c|c|c|c|c|}
\hline $\begin{array}{c}\text { Dipole } \\
\text { moment } \\
\text { Debye }\end{array}$ & $\begin{array}{c}\text { Total } \\
\text { Energy } \\
(\mathrm{kcal} / \mathrm{mol})\end{array}$ & $\begin{array}{c}\text { Electronic } \\
\text { Energy } \\
(\mathrm{kcal} / \mathrm{mol})\end{array}$ & $\begin{array}{c}\text { Heat of } \\
\text { Formation } \\
(\mathrm{kcal} / \mathrm{mol})\end{array}$ & Symmetry & Volume \\
\hline 0.5 & 103.4680 & -407.026 & 139.562 & $\mathrm{CS}$ & $833.03 \mathrm{~A}^{\circ 3}$ \\
\hline
\end{tabular}

Table (3): Thermodynamic parameters for Lansoprazol.

\begin{tabular}{|c|c|c|c|c|c|}
\hline $\begin{array}{c}\text { Dipole } \\
\text { moment } \\
\text { Debyes }\end{array}$ & $\begin{array}{c}\text { Total Energy } \\
(\mathrm{kcal} / \mathrm{mol})\end{array}$ & $\begin{array}{c}\text { Electronic } \\
\text { Energy } \\
(\mathrm{kcal} / \mathrm{mol})\end{array}$ & $\begin{array}{c}\text { Heat of } \\
\text { Formation } \\
(\mathrm{kcal} / \mathrm{mol})\end{array}$ & Symmetry & Volume \\
\hline 2.153 & -108.188 & -714.880 & -133.081 & $\mathrm{C} 1$ & $275.55 \mathrm{~A}^{\circ 3}$ \\
\hline
\end{tabular}

Table (4): thermodynamic parameters for complex.

\begin{tabular}{|c|c|c|c|c|c|}
\hline $\begin{array}{c}\text { Dipole } \\
\text { moment } \\
\text { Debyes }\end{array}$ & $\begin{array}{c}\text { Total Energy } \\
(\mathrm{kcal} / \mathrm{mol})\end{array}$ & $\begin{array}{c}\text { Electronic } \\
\text { Energy } \\
(\mathrm{kcal} / \mathrm{mol})\end{array}$ & $\mathrm{E}_{\text {HOMO }}(\mathrm{ev})$ & $\mathrm{E}_{\mathrm{LUMO}}(\mathrm{ev})$ & $\begin{array}{c}\text { HOMO- } \\
\text { LUMO } \\
\text { energy } \\
\text { gap(ev) }\end{array}$ \\
\hline 2.450 & -882.226 & -492.760 & -7.9024 & 0.2825 & 7.6199 \\
\hline
\end{tabular}




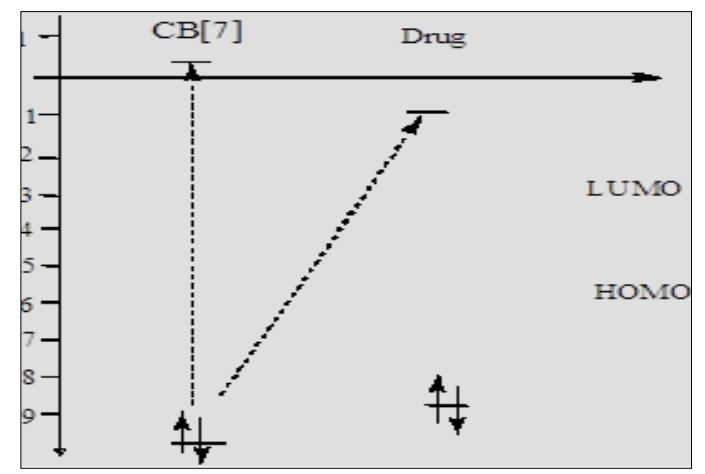

Fig. (5): $E_{\text {Hомо }}(e V)$ and $E_{\text {Lumo }}(e V)$ levels

\section{References:}

[1] Sindelar, V.; Moon, K. and Kaifer, A. 2004. Binding Selectivity of Cucurbit[7[uril: Bis(pyridinium)-1,4xylylene versus 4,4'-Bipyridinium Guest Sites, Org. Lett.2(6): 26652668.

[2] Lagona, J.; Mukhopadhyay, P.; Chakrabarti, S.and Isaacs, L. 2005. The Cucurbit[n]uril Family, Angew. Chem., Int. Ed., 6(44): 4844.

[3] Stella, V. J. and Rajewski, R. A. 1997. Cyclodextrins: Their Future in Drug Formulation and Delivery, Pharm Res, 14(1): 556-567.

[4] Petr, T.; Emanuel M. and Petr V. 2011. DFT Study on the Complexation of Bambus [6] uril with the Perchlorate and Tetrafluoroborate Anions, Acta Chim. Slov.,5( 5): 846-849.

[5] Ruibing, W.; Brendan C.; and Donal H.2009. Stabilization of the base-off forms of vitamin B12 and coenzyme B12 by encapsulation of the $\alpha$-axial 5,6-dimethylbenzimidazole ligand with cucurbit[7] uril, Dalton Transactions, 18(1): 3584-3589.

[6] Dewar, M. and Reynolds, C. 1986. An improved set of mndo parameters for sulfur, computational chemistry,7(1): 140- 143.

[7] Hee-Joon, K.; WooSung J.; Young H. and Kimoon K. 2002. Inclusion of methylviologen in cucurbit[7]uril, PNAS, 99(1): 5009.
[8] Li, L.; Ge, Y.; Huang Z.; Li Y. 2007. Study on the molecular Recognition of per hydroxyl cucurbit[6]uril with methyl orange by Spectroscopic methods, Specrosc. Spectr. Anal, 27(2):1393-1397.

[9] Wyman, I.; Macartney D. 2008. Cucurbit [7]uril host-guest complexes with small polar organic guests in aqueous solution, Org. Biomol. Chem, 6(1): 1796-1801.

[10] Wheate, N.; Kumar P.; Torres A.; Aldrich J. and Price W. 2008. Examination of cucurbit[7]uril and its host-guest complexes by diffusion nuclear magnetic resonance, J. Phys. Chem. B, 112(1): 2311-2314.

[11] Liu, S.; Shukla A.; Gadde S.; Wagner B.; Kaifer A. and Isaacs L.2008. Ternary complexes comprising cucurbit[10]uril, porphyrins and guests. Angew,Chem. Int. Ed, 47(2): 2657-2660.

[12] Liu, J.; Long L.; Huang R. and Zheng, L. 2007. Interesting anioninclusion behavior of cucurbit[5]uril and its lanthanide- capped molecular capsule, Inorg. Chem, 46(4): 10168-10173. 


\section{التكوين والتركيب والخصائص الأكترونية لمعقد دواء لانزوبرازول وurals cucurbit[7]}

$$
\text { وليب مظلوم خلف** }
$$

*مدية حاتم جواد الشمري

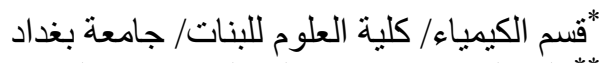

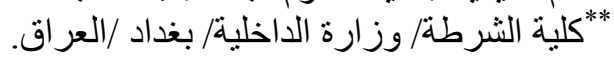

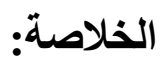

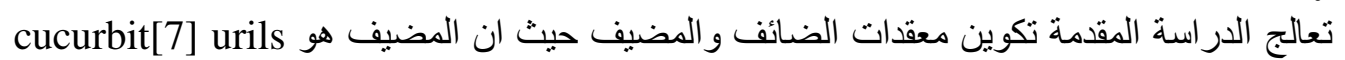

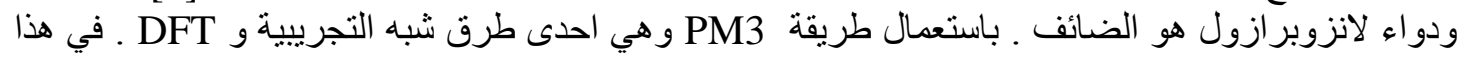

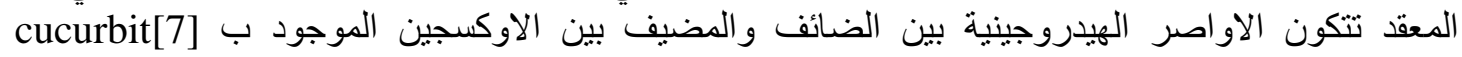

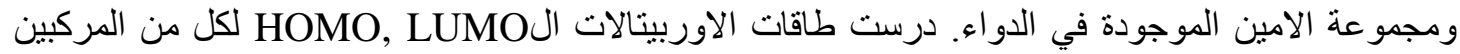
و المعقد المنكون بينت النتائج المستحصلة استقر ارية المعقد المتكون.

الكلمات المفتاحية: معقدات الضائف و المضيف، حسابات طرق شبة التجرييية- PM3، حسابات DFT. 